\title{
PROFESSORES DA ESCOLA BÁSICA REPRESENTADOS NA ESCRITA DE ALUNOS DA LICENCIATURA EM LETRAS
}

\author{
TEACHERS FROM BASIC SCHOOL REPRESENTED \\ IN THE STUDENTS WRITING OF LANGUAGE TRAINING TEACHER
}

\author{
Bárbara de Freitas Farah' \\ Wagner Rodrigues Silva²
}

\begin{abstract}
RESUMO: Investigamos algumas representaçôes de professores da escola básica em relatórios de estágio supervisionado, produzidos por professores em formaçăo inicial. A investigaçấo foi caracterizada como uma pesquisa documental, situada no campo de estudos da Linguística Aplicada. A Linguística Sistêmico-Funcional foi utilizada como teoria de análise linguística dos relatórios. As representaçôes de professores identificadas estăo atreladas diretamente à antinomia tradicional versus inovador, que traduz as impressóes preliminares sobre o trabalho docente na escola básica, construídas pelos professores em formaçấo inicial, tomando como referência saberes teóricos produzidos na universidade.
\end{abstract}

PALAVRAS-CHAVE: estágio supervisionado; letramento do professor; linguística sistêmicofuncional.

ABSTRACT: We investigate some representations of teachers from basic school in internship reports written by pre-service teachers. This study was characterized as a documental research situated in the field of Applied Linguistics. The Systemic Functional Linguistics was used as a theory of linguistic analysis to investigate the reports. Teachers' representations identified in the study are directly linked to traditional versus innovative antinomy that translates the preliminary impressions about teaching job at basic school. These representations were built by pre-service teachers from theoretical knowledge produced at university.

KEYWORDS: supervised teaching internship; teacher's literacy; systemic functional linguistics.

\section{INTRODUÇÃO}

Investigamos representaçôes a respeito dos professores brasileiros da escola básica (PEB), a partir do exame de realizaçóes léxico-gramaticais, no sistema de

Mestre em Letras: Ensino de Língua e Literatura, pela Universidade Federal do Tocantins (UFT); professora da Faculdade Integrada Carajás (FIC). E-mail: barbarafarahmatos@gmail.com.

2 Professor Associado II na Universidade Federal do Tocantins (UFT), Câmpus de Palmas; Bolsista de Produtividade do CNPq. E-mail: wagnerodriguesilva@gmail.com. 
transitividade de oraçóes gramaticais em que professores em formaçăo inicial, denominados, neste artigo, de alunos-mestre, fazem referência ao mencionado profissional do magistério. As representaçóes săo construídas pelos alunosmestre ao relatarem as experiências vivenciadas em estágios supervisionados obrigatórios na escola de ensino básico. Esperamos contribuir para a formaçăo profissional dos alunos-mestre, mostrando a relevância da apropriaçăo de uma consciência mais crítica e propositiva no tocante ao trabalho docente na escola de ensino básico. ${ }^{3}$

O corpus desta pesquisa foi composto por 104 relatórios de estágio, escritos pelos alunos-mestre, entre os anos de 2006 e 2012, na Licenciatura em Letras (Habilitaçâo em Língua Portuguesa), ofertada no Câmpus de Araguaína, na Universidade Federal do Tocantins (UFT). Os relatórios favorecem a pesquisa documental, pois carregam informaçōes sobre as práticas sociais características do complexo espaço de realizaçâo das atividades dos estágios supervisionados obrigatórios, envolvendo instituiçōes de ensino básico e superior. Considerando que os documentos analisados se configuram num gênero textual, podemos afirmar que o exame dos referidos textos possibilita a observaçăo de indivíduos, grupos, comportamentos, práticas, dentre outros aspectos sociais.

A pesquisa se caracterizou predominantemente pelo tratamento qualitativo dos dados, ainda que, em alguns momentos, utilizamo-nos de procedimentos quantitativos para corroborar o exame dos textos dos discentes. Foi situada no campo investigativo da Linguística Aplicada (LA), a partir de uma abordagem teóricometodológica transdisciplinar, desdobrando-se no diálogo entre diferentes disciplinas ou campos do conhecimento científico. Essa abordagem foi complementada pelo paradigma da complexidade assumido na construçâo dos relatórios de estágio como objeto de investigaçăo.

Este artigo está organizado em quatro principais seçôes, além desta Introduçāo, das Consideraçóes finais e das Referências. Em Relatório de estágio como objeto de pesquisa, caracterizamos os documentos selecionados como objeto de investigaçăo e descrevemos as estratégias metodológicas assumidas nesta pesquisa. Em Teoria linguística para microanálise dos dados, sintetizamos as definiçóes das categorias de análise linguística dos dados a partir da Linguística Sistêmico-Funcional (LSF). Em Análise quantitativa dos dados, sintetizamos os resultados produzidos com o exame estatístico de algumas escolhas léxico-gramaticais realizadas pelos alunos-mestre ao produzirem os relatórios de estágio. Esse exame auxilia na compreensăo da escrita reflexiva, característica do gênero focalizado. Finalmente, em Análise qualitativa dos dados, exemplificamos alguns excertos ilustrativos das categorias analíticas caracterizadoras das representaçōes identificadas dos PEB.

Esta pesquisa foi desenvolvida no grupo de pesquisa Práticas de Linguagens - PLES (CNPq/UFT), dentro do projeto "Estudo gramatical-discursivo da escrita reflexiva profissional produzida por professores em formaçáo inicial" (CNPq 446235/2014-8). O artigo sintetiza os resultados da dissertaçấo de mestrado acadêmico da primeira autora deste texto, sob a orientaçấo do segundo autor (FARAH, 2016). 


\section{RELATÓRIO DE ESTÁGIO COMO OBJETO DE PESQUISA}

Os relatórios investigados foram disponibilizados no Centro Interdisciplinar de Memória dos Estágios Supervisionados das Licenciaturas (CIMES), no câmpus universitário de Araguaína. No referido centro de documentaçăo, encontram-se arquivados os relatórios de estágio obrigatório das Licenciaturas em Letras, Matemática, Geografia, Biologia, Química e Física. Foi criado, no segundo semestre de 2009, e tem seu acervo disponibilizado para consulta pela comunidade interessada.

Nesta pesquisa, foram analisados textos escolhidos aleatoriamente a partir das quatro disciplinas de estágio, integrantes da matriz curricular da Licenciatura em Letras (Habilitaçâo em Língua Portuguesa). Os relatórios foram produzidos por diferentes turmas nos anos letivos de 2004, 2010, 2011, 2012 e 2013. A escolha dos textos de turmas diferentes se justifica pelo fato de nem todas terem os relatórios dos quatro estágios cursados arquivados no CIMES. Quanto ao número de relatórios examinados, apresentamos o Quadro 1:

Quadro 1: Quantificação de relatórios de estágio

\begin{tabular}{c|c|c|c|c|c}
\hline $\begin{array}{c}\text { Disciplinas de } \\
\text { Estágio }\end{array}$ & Estágio I & Estágio II & Estágio III & Estágio IV & Total \\
\hline $\begin{array}{c}\text { Número de } \\
\text { relatórios }\end{array}$ & 50 & 26 & 28 & 27 & 131 \\
\hline
\end{tabular}

Fonte: Farah (2016, p. 30)

O Quadro 1 revela que o número de relatórios diminui conforme o avanço dos estágios obrigatórios da licenciatura. Esse fato pode ser justificado pela desistência do curso por alguns acadêmicos ao avançarem nos períodos letivos em que os estágios obrigatórios săo ofertados. As desistências eram motivadas pela năo identificaçâo dos alunos-mestre com as práticas do magistério ou, até mesmo, pelo volume de trabalho demandado nesses períodos da dupla licenciatura, considerando que os acadêmicos já trabalhavam em funçóes diversas fora da universidade, em turnos diferentes da licenciatura cursada. ${ }^{4}$

Frequentemente, o período de estágio obrigatório da licenciatura era marcado por um desafio diferenciado, pois o aluno-mestre precisava utilizar os conhecimentos teóricos na prática profissional na escola de ensino básico, o que, dificilmente, era possibilitado em outros momentos da licenciatura. Cada formador, responsável pelos estágios, assumia estratégias pedagógicas próprias. Precisava acompanhar os alunosmestre em aulas de regência na escola básica, pois o desempenho do acadêmico na escola fazia parte da avaliaçăo, bem como a escrita dos relatórios entregues ao final das disciplinas.

A maioria dos relatórios investigados foi produzida na vigência do antigo Projeto Político Pedagógico do curso, caracterizado pela obrigatoriedade da dupla licenciatura (Habilitaçôes em Língua Portuguesa e Língua Inglesa). A partir de 2009, começou a ser implementada para os novos ingressos no curso a obrigatoriedade da habilitaçấo única. 
Além de instrumento de avaliaçăo, os relatórios podem ser utilizados para facilitar a articulaçáo entre as demandas teóricas e práticas da licenciatura. Săo responsáveis pelo acionamento de espécies de flashes, uma vez que os alunos-mestre capturam algumas lembranças de experiências vivenciadas nas escolas. Inúmeras coisas acontecem simultaneamente durante as atividades dos estágios obrigatórios em escolas básicas, mas os olhares focalizam algumas cenas, tentam compreender as açóes nelas instauradas. A seleçâo das cenas é determinada por diversos fatores, os quais podem ser apreendidos a partir da leitura dos referidos documentos, justificando, portanto, nossa apreensăo dos relatórios como objetos complexos de pesquisa. De acordo com Morin (1990, p. 20), "a complexidade é um tecido (complexus: o que é tecido em conjunto) de constituintes heterogêneos, inseparavelmente associados [...] é efetivamente o tecido de acontecimentos, açōes, interaçōes, retroaçóes, determinaçóes, acasos, que constituem o nosso mundo fenomenal" (itálico do original).

O relatório năo existe por ele mesmo. Atrela-se a questóes internas e externas à própria escrita, como a história de vida dos seus autores. Como outros textos, carrega ideologias e identidades, histórias de vida dos acadêmicos na educaçăo básica e com o formador na universidade. O próprio contexto do estágio supervisionado é complexo, onde o aluno-mestre se depara com uma realidade pouco recordada, haja vista as diferentes trajetórias dos autores como alunos da escola básica. Conforme afirmam Fiad e Silva (2009), ao investigarem relatórios produzidos em diferentes licenciaturas,

Podemos dizer, de início, que as produçóes escritas constituem-se como manifestaçōes de diferentes sujeitos que, de alguma forma, estăo presentes nesses textos. Podemos já supor que os textos apresentam algo em comum, pois os sujeitos estăo escrevendo sobre um mesmo tema, em situaçóes muito semelhantes, para os mesmos interlocutores. Mas também podemos supor que os textos apresentam singularidades, na medida em que os sujeitos podem fazer escolhas, tomar decisôes, diferentemente uns dos outros (FIAD; SILVA, 2009, p. 125).

Para a formaçấo dos professores, é de extrema importância a reflexâo sobre a própria prática profissional. Por meio da escrita reflexiva profissional, característica dos relatórios de estágio, cria-se uma possibilidade de os alunos-mestre desenvolverem a criticidade. Ao ter de escrever sobre as experiências na escola de educaçáo básica, o aluno-mestre tem a oportunidade de selecionar e refletir sobre as experiências vividas. É neste momento único entre o aluno-mestre e sua escrita que ele pode (re)pensar as mais variadas questōes pedagógicas em que se vê inserido. Para Burton (2009), escrever é um processo de extrema relevância para a formaçăo reflexiva do professor. Ainda segundo a autora "Desde que a escrita envolve decisóes sobre o que e como escrever, também envolve alguma forma de avaliaçăo e reflexâo; escritores, conscientemente ou năo, selecionam e analisam o material em algum grau. Assim, a escrita oferece aos professores uma maneira de aprender sobre o que eles fazem" (BURTON, 2009, p. 2; traduçăo nossa).

Ao longo da formaçáo acadêmica, os alunos-mestre passaram por quatro estágios obrigatórios, consequentemente, produziram quatro relatórios para cada habilitaçâo da licenciatura. Na escrita desses textos, os alunos-mestre tendiam a considerar documentos oficiais, com orientaçóes para o ensino de língua, além de se apropriarem de 
literaturas científicas de referência (cf. MELO, 2015). Apresentaram suas concepçóes de ensino de língua e literatura, transparecendo crenças e ideologias próprias ao terem contato com a vida docente. Ainda de acordo com Burton (2009, p. 1),

\begin{abstract}
Escrita reflexiva é um recurso versátil. Escrever năo só apoia a reflexăo e a aprendizagem profissional em muitos ambientes de ensino, mas também pode ser uma atividade prazerosa e sociável. Muitos professores náo têm certeza sobre o que eles pensam antes de escrever, mas acham que escrever sobre a sua prática traz novos insights e entendimento, um sentimento de realizaçáo pessoal e profissional, e uma prontidăo para compartilhar ideias com outros (traduçăo nossa).
\end{abstract}

Esse tipo de escrita pode contribuir de maneira significativa para o modo como o PEB é visto e representado pelo aluno-mestre. Muitas vezes, o referido profissional aparece nos relatórios de maneira superficial, configurando-se como um ator secundário no cenário focalizado pelo autor. A escrita reflexiva pode contribuir para estreitar a interaçăo entre os atores envolvidos nos estágios obrigatórios, surgindo, a partir dessa reflexăo, práticas pedagógicas para o fortalecimento das instituiçóes representadas.

A escrita reflexiva profissional abre caminhos para que possamos discutir a própria postura do aluno-mestre, refletindo, discursiva e linguisticamente, sobre a formaçâo acadêmica e o campo de atuaçăo profissional. Sendo assim, o relatório deve funcionar como instrumento na construçấo de uma prática de reflexăo crítica sobre a açăo pedagógica do professor em formaçăo inicial. Conforme Silva (2014, p. 39),

a escrita reflexiva profissional pode funcionar como uma estratégia didática que fortalece a abordagem prática demandada na licenciatura, a exemplo da autonomia profissional necessária para transitar entre textos de diferentes gêneros, conforme as exigências instauradas no local de trabalho.

Por fim, salientamos que a estrutura dos relatórios é bastante diversificada, o que pode ser explicado, de acordo com Silva (2012, p. 287), pela "falta de consenso entre os profissionais responsáveis por coordenar e ministrar os estágios supervisionados a respeito da operacionalizaçâo das orientaçôes oficiais sobre a disciplina". Conforme tematizamos na próxima seçấo deste artigo, năo existe texto desprendido do seu contexto de produçấo e circulaçăo, assim o exame dos relatórios possibilita a compreensâo das práticas de formaçâo inicial do professor.

\title{
TEORIA LINGUÍSTICA PARA MICROANÁLISE DOS DADOS
}

Ao produzir os relatórios de estágio, os alunos-mestre fazem escolhas lexicais e gramaticais, as quais se configuram como pistas linguístico-discursivas para compreensâo do contexto de produçâo e circulaçâo do referido gênero. Quando analisadas, tais escolhas nos ajudam a identificar algumas representaçōes sobre os PEB, os quais, infelizmente, nem sempre sâo concebidos como leitores dos referidos relatórios de estágio, haja vista a ausência de uma interaçáo mais estreita entre os atores sociais, representantes das instituiçôes de ensino básico e superior, envolvidos na efetivaçâo dos estágios.

ALinguística Sistêmico-Funcional(LSF) nos permite realizar uma análise linguísticodiscursiva do gênero investigado nesta pesquisa. Caracteriza-se como uma abordagem 
sociossemiótica, pois, ao disponibilizar categorias de análise linguística para o exame da materialidade textual, a teoria possibilita a compreensáo das práticas sociais características de contextos específicos. Dentro da LSF, existe uma tentativa de entender por meio da produçâo de significados da linguagem como se dâo as relaçōes entre os usuários da língua, suas experiências e seus papéis sociais em situaçóes reais de uso da linguagem. Com o auxílio da referida teoria, podemos "começar a analisar e explicar como os significados săo feitos nas interaçōes linguísticas diárias" (EGGINS, 2004, p.1).

Utilizando-nos dos termos de Bawarshi e Reiff (2013, p. 47), esclarecemos que funcional "diz respeito ao trabalho que a linguagem realiza dentro de determinados contextos", ao passo que sistêmico "diz respeito à estrutura ou organizaçâo da linguagem de modo que ela possa ser usada para fazer determinadas coisas dentro daqueles contextos". Portanto, as categorias gramaticais săo escolhidas pelos usuários da língua a partir das opçōes linguísticas disponibilizadas nos diferentes sistemas da língua. Tais escolhas săo motivadas por demandas contextuais e propósitos interativos, manifestando inúmeras funçôes exercidas pela linguagem.

A LSF é uma teoria social por focalizar a análise textual a partir de contextos de referência. Parte da situaçăo de uso da linguagem dentro da sociedade. O termo social está incluso na teoria pelo fato das relaçôes se darem através da linguagem, dos processos e contextos sociais, para estabelecer um sistema de valores e ideologias de uma cultura (cf. HALLIDAY; HASAN, 1989)

Como usuários da língua, fazemos escolhas léxico-gramaticais específicas para a elaboraçáo textual a partir de configuraçōes contextuais. As estruturas gramaticais desempenham funçôes de linguagem dentro de um texto, operando no nível da oraçâo. Essas últimas sâo denominadas de metafunçōes: ideacional; interpessoal; e textual (cf. EGGINS, 2004; HALLIDAY; MATTHIESSEN, 2004; 2014). As três metafunçôes da linguagem se realizam articuladamente nas oraçôes gramaticais, significando, respectivamente: representaçâo; troca; e mensagem. As metafunçôes sâo realizadas gramaticalmente e estruturam-se textualmente em razâo dos significados contextualizados.

A metafunçăo ideacional é responsável pela significaçăo da representaçăo das coisas no mundo a partir de escolhas linguísticas realizadas pelos usuários (EGGINS, 2004). Está ligada ao Sistema de TRANSITIVIDADE. A partir dos processos, dos participantes e das circunstâncias, traz um significado experiencial, ou seja, significa as experiências e vivências de mundo do indivíduo, tendo uma funçăo representacional, além de uma funçăo lógica, que, segundo Gouveia (2009, p. 16), "corresponde à organizaçâo lógica dos conteúdos, ao modo como estruturamos a nossa experiência do mundo", e está ligado ao complexo oracional.

Na metafunçăo ideacional, existem os processos (representaçôes linguísticas de açōes), os quais se dividem em seis tipos com características próprias, além dos participantes e das circunstâncias. Sobre os processos, Furtado da Cunha e Souza (2011, p. 68) afirma serem "elementos responsáveis por codificar açōes, eventos, estabelecer relaçōes, exprimir ideias e sentimentos, construir o dizer e o existir; realizam-se através de sintagmas verbais".

Na Figura 1, apresentamos os seis tipos de processos, que possuem participantes específicos e apresentam diferentes funçōes: Relacional; Verbal; Mental; Comportamental; Material; e Existencial. 
Figura 1: Tipos de processo

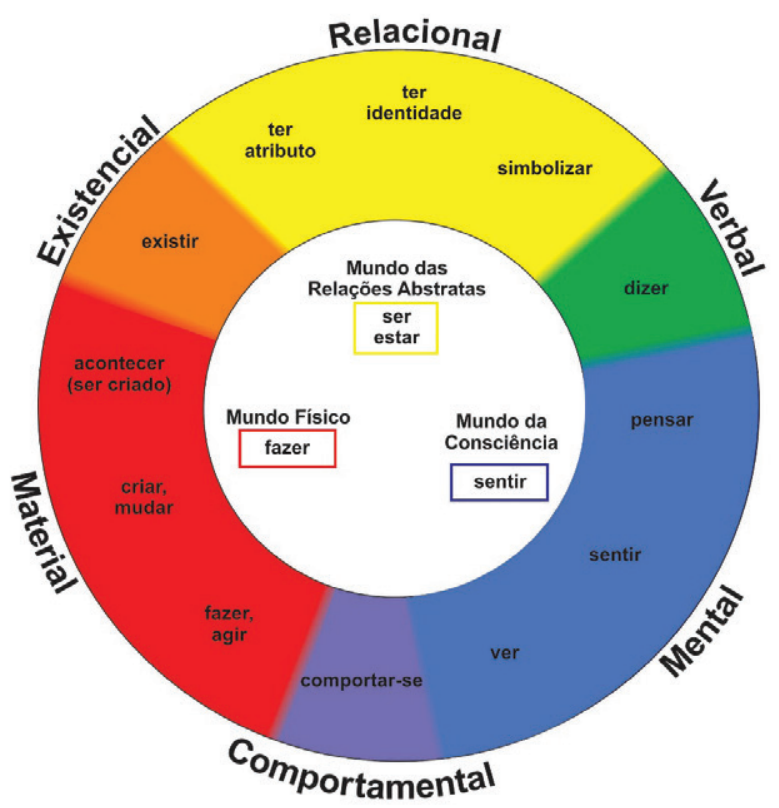

Fonte: MENDES (2014, p. 4)

Conforme representado, na Figura 2, para cada tipo de processo, temos um participante específico dentro da oraçăo. No Esquema 1, apresentamos os tipos de processo e subprocesso e seus respectivos participantes principal (com funçăo de sujeito) e secundário (com funçáo de complemento do verbo).

Esquema 1: Sistema de escolha de transitividade

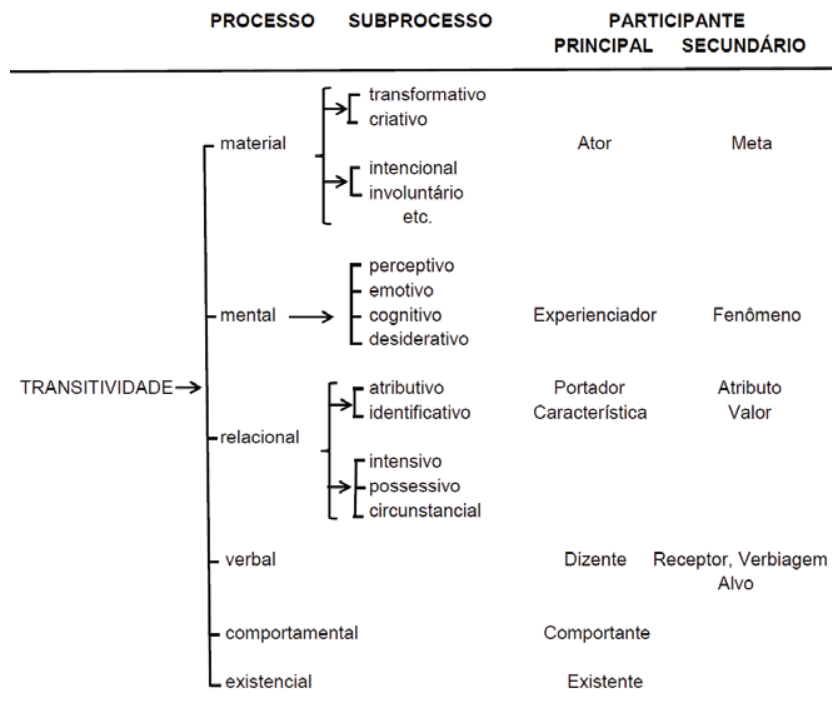

Fonte: Silva (2014, p. 81)

No sistema de TRANSITIVIDADE, há três tipos de processos principais (Materiais; Mentais; e Relacionais) e três secundários (Comportamentais; Verbais; e Existenciais). Para cada tipo de processo, existe um participante e, em cada oraçăo, existem um tipo 
ou mais de participante, formando os chamados grupos nominais. Já as circunstancias "săo realizadas através de grupos adverbiais e frases preposicionais" (EGGINS, 2004, p. 222), trazem informaçôes extras aos processos dentro das oraçôes.

Como a LSF trabalha com a noçâo de contexto que, consequentemente, envolve escolhas léxico-gramaticais, é o Sistema de TRANSITIVIDADE que cria significados sobre as representaçōes do mundo real e imaginário. Sendo assim, acreditamos que a metafunçăo ideacional, com seu significado experiencial, auxilia-nos a identificar, linguisticamente e discursivamente as representaçôes dos PEB dentro dos relatórios de estágio supervisionado, além de podermos observar, a partir das escolhas dos processos, se o aluno-mestre desenvolve uma escrita reflexiva.

\section{ANÁLISE QUANTITATIVA DOS DADOS}

Apresentamos uma análise quantitativa do número total de processos identificados nos dados focalizados. Inspiramo-nos no trabalho de SILVA (2014), que também faz uma análise quantitativa dos processos em relatórios de estágio supervisionado, só que a partir da comparaçăo entre dois diferentes gêneros (nota de campo e relatório de estágio). O enfoque investigativo do autor envolvia o trabalho de retextualizaçâo.

Em nossa pesquisa, a análise quantitativa foi realizada com um único gênero, a partir do qual se moldam os textos selecionados nas quatro disciplinas focalizadas de estágio. Tal procedimento foi realizado com propósito de produzir um mapeamento geral das representaçóes do PEB, além de tentar identificar como se deram tais representaçóes à medida que os alunos-mestre avançaram ao longo das disciplinas de estágio supervisionado. Buscamos os processos ligados ao PEB como sujeito da oraçăo gramatical e também as ocorrências de retomadas por pronomes (ele/ela) também em posiçăo de sujeito.

Para efetuarmos a identificaçâo e a quantificaçăo dos processos, utilizamos a ferramenta digital Concord, disponibilizada no WordSmith Tools (SCOTT, 2009). O programa colabora para a análise de dados em grande quantidade. Com a ferramenta Concord, foi possível inserir todo nosso corpus de uma só vez e criar uma lista com todos os excertos em que apareceu o PEB como sujeito da oraçáo e os pronomes que fizessem referência a ele. Dessa maneira, facilitou a identificaçăo e quantificaçăo dos processos ligados ao PEB.

Na Tabela 1 e no Gráfico 1, sâo apresentados os quantitativos dos processos ligados ao PEB como participante sujeito no sistema de TRANSITIVIDADE. Consideramos os relatórios produzidos em cada disciplina de estágio supervisionado. 
Tabela 1: Quantificação dos tipos de processo

\begin{tabular}{|c|c|c|c|c|c|c|c|c|c|c|c|c|}
\hline PROCESSO & \multicolumn{2}{|c|}{ Verbal } & \multicolumn{2}{|c|}{ Material } & \multicolumn{2}{|c|}{ Mental } & \multicolumn{2}{|c|}{ Relacional } & \multicolumn{2}{|c|}{ Comportamental } & \multicolumn{2}{|c|}{ Total } \\
\hline RELATORIO & $\mathrm{N}$ & $\%$ & $\mathrm{~N}$ & $\%$ & $\mathrm{~N}$ & $\%$ & $\mathrm{~N}$ & $\%$ & $\mathrm{~N}$ & $\%$ & $\mathrm{~N}$ & $\%$ \\
\hline I & 108 & 33.33 & 167 & 51.54 & 15 & 4.62 & 20 & 6.18 & 14 & 4.33 & 324 & 55.10 \\
\hline II & 18 & 24.33 & 41 & 55.40 & 2 & 2.70 & 9 & 12.17 & 4 & 5.40 & 74 & 12.58 \\
\hline III & 22 & 27.16 & 48 & 59.25 & 4 & 4.94 & 7 & 8.65 & 0 & 0 & 81 & 13.77 \\
\hline IV & 29 & 26.60 & 52 & 47.70 & 8 & 7.35 & 14 & 12.85 & 6 & 5.50 & 109 & 18.55 \\
\hline TOTAL & 177 & 30.10 & 308 & 52.38 & 29 & 4.93 & 50 & 8.50 & 24 & 4.09 & 588 & 100 \\
\hline
\end{tabular}

Fonte: Farah (2016, p. 76)

Conforme a Tabela 1, nos textos do Estágio I, há um número superior de processos ligados ao PEB (324 processos) em comparaçâo aos outros relatórios: Estágio II (74); Estágio III (81); e Estágio IV (109). Algo que também nos chamou a atençâo foi que, nos textos dos Estágios II e III, encontramos menos processos em comparaçăo ao último relatório. Em todos os relatórios, o número de ocorrência de processos Materiais e Verbais é superior ao dos processos Mentais, Relacionais e Comportamentais.

Esses resultados se justificam pelos objetivos diferenciados das disciplinas de estágio supervisionado. No Estágio I, o aluno-mestre vai à escola apenas para observar especialmente o trabalho desenvolvido pelo $\mathrm{PEB}$, enquanto que, nas demais disciplinas, os alunos-mestre iniciam a própria prática de regência de aulas e observam poucas aulas do PEB, portanto, a escrita reflexiva possibilita que ele se volte para a própria açâo profissional. Sendo assim, no relatório de Estágio I, o aluno-mestre acaba discorrendo mais especificamente sobre o PEB, colaborador do estágio supervisionado, resultando, consequentemente, em mais processos atrelados ao professor enquanto participante, ocupando a posiçấo sintática de sujeito da oraçăo gramatical.

\section{Gráfico 1: Relatórios por disciplina e tipos de processo}

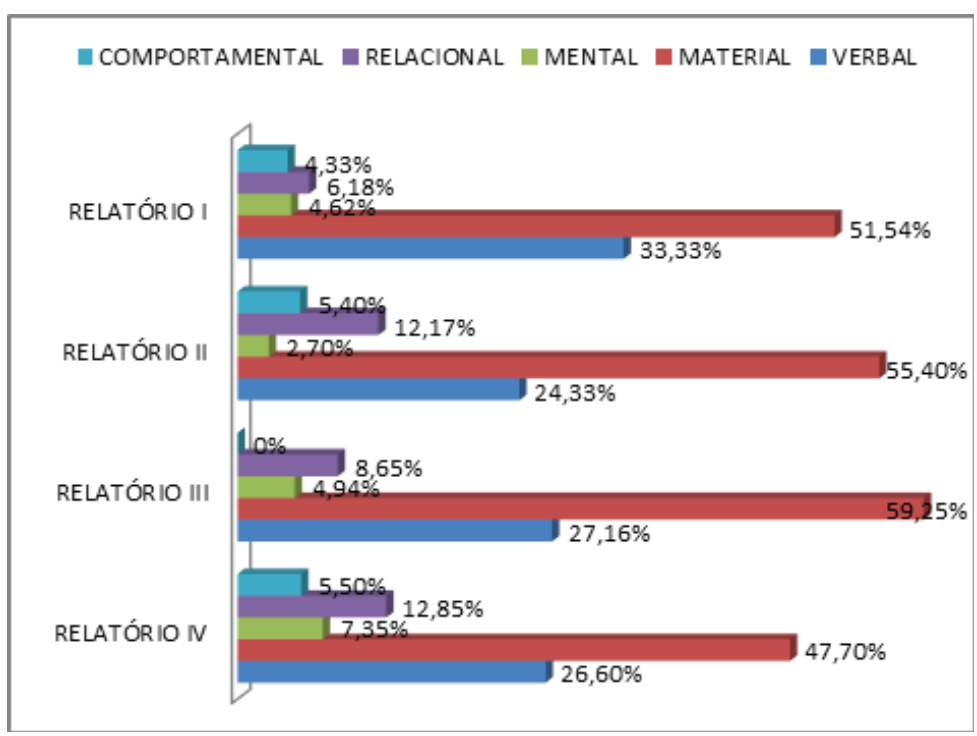

Fonte: Farah (2016, p. 77) 
A maior ocorrência dos processos Materiais e Verbais nos revela que os professores da educaçáo básica săo representados como atores sociais que estăo sempre fazendo algo ou falando, o que é bem característico da profissăo. A maneira do aluno-mestre representar o PEB ocorre a partir de um olhar externo e superficial. $O$ aluno-mestre precisa ser preparado para se utilizar de um olhar mais sensível e investigativo, capaz de compreender o que leva o PEB a realizar determinadas práticas pedagógicas.

A reduzida ocorrência de processos Mentais na escrita dos documentos investigados indica falta de reflexăo sobre o PEB por parte do aluno-mestre, focalizando as experiências percebidas explicitamente. Quanto ao baixo índice do processo Relacional, certamente, justifica-se pelo fato do aluno-mestre tentar năo se comprometer fazendo julgamentos diretos sobre o professor colaborador, já que esse processo caracteriza e identifica os participantes envolvidos. No trabalho de Silva (2014), também encontramos esse resultado em relaçâo ao processo Relacional ser menos frequente na escrita do relatório de estágio e nas notas de campo, gêneros acadêmicos analisados pelo autor.

Comparando os quatro estágios, com base nos nossos dados, podemos afirmar que há um aumento da representaçâo do PEB conforme os alunos-mestre avançam ao longo das disciplinas de estágio supervisionado obrigatório. Afirmamos isso pelo fato de as ocorrências de processos ligados ao professor colaborador em posiçáo de participante sujeito aumentarem gradativamente: 74 nos relatórios do Estágio II; 81 nos relatórios do Estágio III; e 109 nos relatórios do Estágio IV. Desconsideramos aqui os relatórios do Estágio I pelo fato dos textos da disciplina terem mais processos atrelados aos PEB que os outros relatórios, o que é justificado pelo fato do primeiro estágio se restringir à observaçăo de aulas pelos alunos-mestre.

Em síntese, ao compararmos os relatórios dos estágios de regência de aulas, observamos, claramente, que as representaçôes sobre o PEB aumentam até o fim do estágio. Apesar de isso náo indicar uma reflexăo crítica por parte do aluno-mestre, entendemos como algo positivo, pois é importante que o estagiário enxergue o professor colaborador de alguma maneira e apresente isso na escrita do relatório, o que pode significar maior aproximaçâo entre as instituiçôes de ensino.

\section{ANÁLISE QUALITATIVA DOS DADOS}

Nos relatórios investigados, o núcleo das representaçôes sobre os PEB corresponde à antinomia tradicional versus inovador, propagada nos discursos produzidos pelos alunos-mestre. Como elementos periféricos, ligados ao núcleo citado, identificamos algumas representaçóes que, nesta pesquisa, foram concebidas como categorias analíticas dos dados: professor dependente das práticas da tradiçāo escolar; professor dependente do livro didático; professor inovador das práticas escolares; professor interlocutor dos alunos-mestre. A Figura 2 é uma tentativa de síntese das categorias utilizada no exame dos dados, as quais năo săo excludentes, mas podem aparecer simultaneamente nos relatórios. 
Figura 2: Representações do professor da escola básica

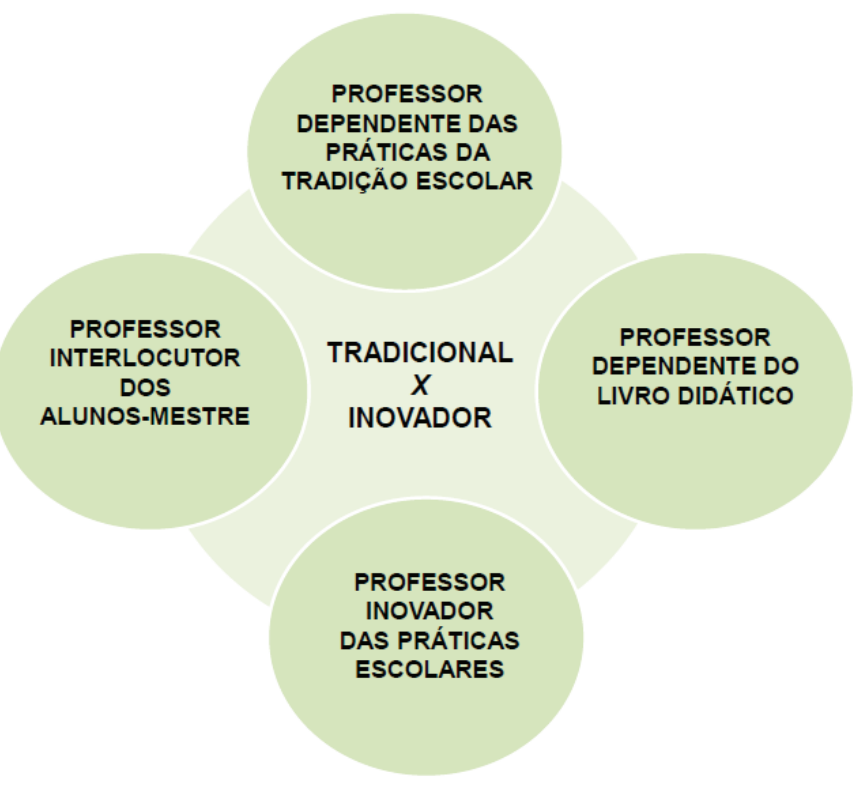

Fonte: elaboração dos autores.

Os componentes oracionais das análises estâo identificados da seguinte forma: os Processos estăo em negrito (quando se referirem ao PEB como sujeito gramatical) ou em itálico (quando se referirem ao aluno-mestre como sujeito gramatical); as Circunstâncias estâo em sublinhado negrito (ao se referirem ao PEB); e o Tema está em sublinhado simples. Os excertos analisados foram reproduzidos sem alteraçóes linguísticas e sâo representativos dos tipos de representaçōes identificadas. Nos exemplos, săo informados: o estágio supervisionado a qual o relatório pertence; o ano de produçâo textual; e a seçăo de onde se origina o excerto.

O Exemplo 1 ilustra a representaçăo do PEB como um profissional mais resistente às inovaçôes nas aulas de Língua Portuguesa, o qual nâo se utiliza de metodologias adequadas nas aulas observadas pelos alunos-mestre.

\section{EXEMPLO 1}

Nas aulas observadas constatei que a professora năo utiliza novas tecnologias, mantendo-se em um modelo tradicional, no qual a exposiçăo do conteúdo é feita somente de forma oral e escrita. E esta forma conservadora de conduzir as aulas náo propicia a curiosidade dos alunos sobre os conteúdos estudados e consequentemente afeta o processo de ensino-aprendizado (Estágio I, 2010, desenvolvimento).

No início do Exemplo 1, há indícios de reflexăo crítica na escrita do relatório de estágio a partir da escolha do Processo Mental de Percepçăo (constatei), onde o próprio aluno-mestre é o Experienciador. A professora colaboradora é o ator do Processo Material (utiliza), acompanhado do advérbio de negaçăo (nâo) e tem como Meta novas tecnologias. Em seguida, com o uso do Processo Relacional (mantendo-se) e da Circunstância em um modelo tradicional, o aluno-mestre utiliza a antinomia tradicional versus inovador para fazer a representaçấo da PEB. A professora da educaçáo 
básica aparece como participante responsável pelo procedimento pedagógico relatado. Este procedimento é descrito negativamente pelo aluno-mestre quando destaca o método utilizado pela PEB a partir da forma verbal (é feita), responsável pelo Processo Material. O núcleo está no verbo fazer. O somente funciona como uma modalizaçăo restritiva, ele caracteriza a maneira como os conteúdos săo expostos (forma oral e escrita). Ou seja, o aluno-mestre endossa o que foi dito anteriormente sobre nenhuma ocorrência de práticas pedagógicas envolvidas com tecnologias.

Em seguida, o aluno-mestre utiliza a informaçăo de um Rema para produzir o Tema da oraçâo seguinte (E esta forma conservadora), dando coesăo ao seu texto com o intuito de dar continuidade em seu argumento de que a professora năo está aberta às novas possibilidades dentro da sala de aula. Manter-se conservadora traz consequências no ensino-aprendizado pelo fato de nâo despertar a curiosidade ou apreender a atençâo dos alunos. Mas resta-nos uma pergunta de difícil resposta ignorada no relatório: por que alguns professores assumem metodologias pedagógicas criticadas? A resposta para o referido questionamento demanda uma nova pesquisa.

Conforme ilustrado no Exemplo 2, aos olhos dos alunos-mestre, o PEB continua sendo representado como um profissional adepto de estratégias pedagógicas tradicionais. Para o aluno-mestre, o livro didático é um recurso facilitador das práticas pedagógicas, mas năo garante o desenvolvimento significativo das competências dos aprendizes e, por isso, nâo pode ser tido como o único instrumento pedagógico de mediaçâo em sala de aula.

\section{EXEMPLO 2}

Embora se mostrasse envolvida pela profissâo e pelo prazer de ensinar, muitas vezes o tradicionalismo/uso do livro era motivo para que os alunos năo sentissem um maior interesse pelas aulas, pois a monotonia acaba gerando um comportamento meio incoerente por parte dos alunos, como por exemplo, conversas paralelas (Estágio III, 2013, desenvolvimento).

No Exemplo 2, o conectivo contrajuntivo Embora funciona como Tema Textual da oraçăo e marca uma contrajunçăo argumentativa. $\mathrm{O}$ autor do relatório apresenta o Processo Relacional (mostrasse) que tem como Portador a professora da educaçâo básica, apresentando como atributo a forma nominal envolvida, ligada às Circunstancias pela profissáo e pelo prazer de ensinar. O entusiasmo da professora foi caracterizado como insuficiente para garantir um bom desempenho da profissional em sala de aula. E, para isso, mais uma vez, o aluno-mestre associa o método do PEB à antinomia tradicional versus inovador. Em síntese, justifica a opiniâo pelo fato da professora colaboradora fazer uso do livro didático e afirma que a desmotivaçăo dos alunos seria consequência dessa prática.

Diferentemente dos excertos ilustrados previamente, no Exemplo 3, o aluno-mestre representa positivamente o PEB, ao relatar a metodologia utilizada para o ensino de leitura e escrita dentro da escola. 0 trabalho com práticas de leitura e escrita também se configura como um desafio para a academia. 


\section{EXEMPLO 3}

Observamos que a prática docente da professora contrasta em alguns aspectos com o que costumamos discutir na academia, principalmente no ensino de gramática, porém ficou claro para nós que, apesar dela fazer uma divisăo no estudo da língua (gramática x leitura e produçâo escrita), essa conseguiu, através do incentivo à leitura e da escrita de textos, fazer com que seus alunos tenham um ótimo nível de letramento (Estágio II, 2010, Conclusăo).

No Exemplo 3, o aluno-mestre utiliza o Processo Mental (observamos), trazendo uma marca reflexiva explícita, que tem o aluno-mestre como Experienciador, um participante consciente. O aluno-mestre faz uma representaçâo da PEB que constitui um sintagma preposicionado que particulariza o núcleo do sintagma nominal (prática docente) a fim de fazer uma comparaçăo entre sua prática pedagógica e discussôes teóricas dentro da universidade. Com os usos dos processos materiais fazer e conseguiu, o PEB exerce a funçáo de Ator responsável pelo processo. Aparentemente, a representaçăo da PEB náo parece ser positiva, principalmente em relaçăo ao ensino de gramática, mas podemos observar pelo uso dos conectivos contrajuntivos (porém; apesar) que o aluno-mestre encerra fazendo o contrário do esperado. A representaçáo passa a ser positiva, elogiando a PEB pelo incentivo às práticas de leitura e produçấo escrita. 0 que parece fazer falta é a descriçâo desse método, que segundo os alunos-mestre, fez com que os alunos atingissem um ótimo nível de letramento. Resta ainda ao leitor do relatório a curiosidade no tocante ao nível referido, năo explicado pelo autor.

Ao compararmos os relatórios dos quatro estágios obrigatórios da licenciatura focalizada, as representaçóes dos PEB sofrem algumas mudanças ao longo das disciplinas. No Estágio I, caracterizado pela etapa exclusiva de observaçâo de aulas, predominam representaçôes negativas acerca do PEB. Após esta constataçăo, dois relatórios nos chamaram a atençấo justamente por contrariarem as representaçóes negativas. 0 Exemplo 4 ilustra um desses relatórios mencionados.

\section{EXEMPLO 4}

Existem momentos em nossas vidas em que é preciso ceder para poder adquirir mais conhecimento, no caso do estágio conversar com a professora foi simplesmente inacreditável uma vez que o nosso pensamento era de que năo havia interesse por parte da professora em ministrar as suas aulas. No momento em que questionamos a professora sobre seu método de aula, ela foi gentil e sincera ao nos explicar que: “Dentro de uma sala do ensino público, o professor tem acesso a diferentes situaçôes que exigem uma adaptaçâo profunda e reflexiva por parte do profissional. Ser professor, nada mais é do que adaptar-se a realidades diferentes, adequar-se a problemas exteriores e além disso, conseguir dar a sua aula e cumprir com seu conteúdo." (Estágio I, 2010, Introduçâo).

No Exemplo 4, os alunos-mestre iniciam seu relatório com o Processo Existencial (existem) e o Existente (momentos em nossa vida). Com os usos do Processo Relacional (é), da Forma Nominal (preciso) e do Núcleo da Forma Verbal (ceder), é exposta a 
informaçâo de que alguma mudança ocorreu nas representaçóes dos alunos-mestre durante o estágio supervisionado. Em seguida, aparece o Processo Verbal de atividade de fala (conversar) com seu interlocutor (a professora) e o Processo Verbal (explicar) que tem a professora como dizente. Tal diálogo é caracterizado a partir do uso do Processo Relacional (foi) com seu atributo (inacreditável). Os alunos-mestre descrevem tal experiência como proveitosa. Afirmaram representar a professora colaboradora de uma maneira negativa e, após o diálogo, puderam refletir melhor e perceberam que estavam fazendo julgamentos precipitados sobre a profissional.

Certamente, nas situaçôes que deram origem às representaçōes negativas do PEB, identificadas nesta pesquisa, faltou um maior diálogo entre os atores sociais representantes das instituiçôes de ensino envolvidas, assim como também mostrou a pesquisa desenvolvida por Silva, Silva e Borba (2016), ao investigarem complexos oracionais nos relatórios das Licenciaturas em Letras (Habilitaçōes em Língua Portuguesa e Língua Inglesa) e em Matemática. O diálogo pode minimizar as tensōes ou possíveis conflitos instaurados entre a escola e a universidade.

\section{CONSIDERAÇÕES FINAIS}

Esta pesquisa revelou que, na licenciatura focalizada, a escrita do relatório de estágio continua refém da burocracia acadêmica. Frequentemente, as referências feitas ao PEB săo superficiais ou simplificadoras, sem uma reflexăo crítica que proporcione a compreensáo das práticas pedagógicas observadas no contexto escolar. Nas categorias analíticas, caracterizadas pela crítica às metodologias assumidas e aos usos do livro didático, observamos discursos vagos construídos pelos alunos-mestre. Culpam o professor sem complexificar o olhar sobre o desafiador contexto da escola básica. 0 relatório torna-se uma ferramenta para julgar o professor e năo para desencadear o aprofundamento das reflexóes sobre o trabalho docente.

A intervençáo do professor orientador da disciplina de estágio pode trazer benefícios, especialmente quando a prática de reescrita textual é utilizada, proporcionando o desenvolvimento de uma formaçáo inicial mais sustentável do professor, conforme também revelaram outras pesquisas desenvolvidas na LA (MELO, 2015; MENDES; 2014; SILVA; SANTOS; FARAH, 2016; SILVA; SILVA; BORBA, 2016).

A partir das categorias analíticas de representaçôes positivas do PEB, encontramos um fato bastante relevante. Há momentos em que os alunos-mestre relatam terem dialogado com o professor da educaçâo básica e, depois disso, terem compreendido suas práticas, seus métodos. Antes do diálogo, considerando apenas as aulas observadas, os professores foram desaprovados. Em outras palavras, após um contato mais estreito com o PEB, os alunos-mestre refletem mais criticamente, complexificam a situaçáo vivenciada. Năo enxergam mais apenas uma parte do observado, vâo além, passam a enxergar a situaçâo por diferentes perspectivas.

As representaçôes negativas do PEB denunciam que há uma desarmonia entre os atores sociais envolvidos no estágio obrigatório e, consequentemente, entre as instituiçóes educacionais envolvidas. Os alunos-mestre precisam ter consciência de que o PEB é um ator social que pode colaborar para a formaçăo inicial do professor nas licenciaturas. A disciplina de estágio supervisionado só terá seus objetivos atingidos, 
resultando numa sólida formaçăo inicial de professores, quando universidade e escola se virem como parceiras, compartilhando interesses comuns e complementáveis.

Finalmente, entre outros fatos, os resultados da pesquisa, sintetizada neste artigo, endossam que a escrita reflexiva do relatório pode levar o aluno-mestre a ensinar e aprender com motivaçăo e, sobretudo, com compromisso. Os futuros professores devem encontrar sentido nas práticas profissionais apropriadas. Para tanto, o formador precisa subsidiar usos mais sustentáveis dos relatórios nas licenciaturas, potencializando a reflexăo pela escrita. 


\section{REFERÊNCIAS}

BAWARSHI, A. S.; REIFF, M. J. Gênero: história, teoria, pesquisa, ensino. Traduçăo Benedito Gomes Bezerra. Săo Paulo: Parábola, 2013.

BURTON, J. Reflective Writing - Getting to the Heart of Teaching and Learning. In:

et al. (Ed.). Reflective Writing: a Way to Lifelong Teacher Learning. Berkeley: TESL-EJ, 2009. pp. 1-11.

EGGINS, S. An Introduction to Systemic Functional Linguistics. 2nd. Ed. London: Continuum, 2004.

FARAH, B. de F. Representaçóes dos professores da escola básica em relatórios de estágio supervisionado das licenciaturas: escrita reflexiva e realizaçóes léxico-gramaticais. 2016. 103f. Dissertaçăo (Mestrado em Letras: Ensino de Língua e Literatura) - Universidade Federal do Tocantins, Araguaína, 2016.

FIAD, R. S.; SILVA, L. L. Escrita na formaçăo docente: relatos de estágio. Acta Scientiarum: Language and Culture. Maringá: UEM, v. 31, n. 2, pp. 123-131, 2009.

FURTADO DA CUNHA, M. A. F. da; SOUZA, M. M. Transitividade e seus contextos de uso. Săo Paulo: Cortez, 2017.

GOUVEIA, C. A. M. Texto e Gramática: Uma introduçāo à linguística sistémico-funcional. Revista Matraga, 2009. v.16, n. 24, pp. 13-49.

HALLIDAY, M. A. K.; HASAN, R. Language, context, and text: aspects of language in social-semiotic perspective. Oxford: Oxford University Press, 1989.

$\therefore$ MATTHIESSEN, C. M. I. M. An Introduction to Functional Grammar. Hodder Education, 2004.

2014.

. Halliday's Introduction to Functional Grammar. 4th. Ed. London: Routledge,

MELO, L. C. Formas Linguísticas de Inscriçâo do Outro e do Eu-Mesmo na Escrita Reflexiva Acadêmico-Profissional de Relatórios de Estágio de Professores de Língua. 2015. 167f. Tese (Doutorado em Letras: Ensino de Língua e Literatura) - Universidade Federal do Tocantins, Araguaína, 2015.

MENDES, A. S. Reescrita de relatório de estágio supervisionado como prática sustentável na formaçâo inicial do professor. 2014. 118f. Dissertaçăo (Mestrado em Letras: Ensino de Língua e Literatura) - Universidade Federal do Tocantins, Araguaína, 2014.

MORIN, E. Introduçăo ao pensamento complexo. $5^{a}$ ed. Lisboa: Instituto Piaget, 1990.

SCOTT, M. Word Smith Tools. Oxford: Oxford University Press, 2009.

SILVA, W. R. Proposta de análise textual-discursiva do gênero relatório de estágio supervisionado. Documentaçăo de Estudos em Linguística Teórica e Aplicada (DELTA). Săo Paulo: PUCSP, v. 28, n. 2, pp. 281-305, 2012.

. Reflexăo pela escrita no estágio supervisionado da licenciatura: pesquisa em Linguística Aplicada. Campinas: Pontes Editores, 2014. 
; SANTOS, J. S.; FARAH, B. de F. Sustentabilidade e letramento professor em formaçâo inicial: demandas para atividades acadêmicas de ensino e de pesquisa. In: GONÇALVES, Adair V.; BUIN, Edilaine; CONCEIÇÂO, Rute I. S. (Orgs.). Ensino de língua portuguesa para a contemporaneidade: escrita, leitura e formaçăo docente. Campinas: Pontes Editores, 2016, p. 85-109.

.; SILVA, K. L. S.; BORBA, L. de C. Construçăo da reflexăo na escrita acadêmica por professores em formaçăo inicial. Revista Brasileira de Linguística Aplicada. Belo Horizonte: UFMG/ALAB, v. 16, n.2, pp. 277-308, 2016. 